\title{
CYCLING OF NUTRIENTS AND SILICON IN PIGEONPEA AND PEARL MILLET MONOCULTURE AND INTERCROPPING ${ }^{(1)}$
}

\author{
Carlos Alexandre Costa Crusciol ${ }^{(2)}$, Jayme Ferrari Neto ${ }^{(3)}$, Rogério Peres Soratto $^{(4)}$ \& \\ Claudio Hideo Martins da Costa ${ }^{(3)}$
}

\begin{abstract}
SUMMARY
In a no-tillage system, cover crops must be used that combine shoot dry matter production and nutrient recycling. The aim of this study was to evaluate shoot dry matter production, decomposition rate and macronutrient and silicon release from pigeonpea and pearl millet in monoculture and intercropping systems. A randomized block design was used with a $3 \times 6$ factorial arrangement, with four replications. The first factor consisted of three cover crops (pigeonpea, pearl millet and intercropping of these cover crops) and the second consisted of six sampling times $[0,18,32,46,74$ and 91 days after desiccation (DAD)]. Pearl millet produced greater amounts of shoot dry matter and content of N, P, K, Ca, Mg, S, C and Si and had a higher decomposition rate and macronutrient and Si release than the other cover crops. The rates of decomposition and daily nutrient release from shoot dry matter were highest in the first period of evaluation (0-18 DAD). Over time, the $\mathrm{C} / \mathrm{N}$, $\mathrm{C} / \mathrm{P}$ and $\mathrm{C} / \mathrm{S}$ ratios increased, while $\mathrm{C} / \mathrm{Si}$ and the decomposition rate decreased. Potassium was the nutrient most quickly released to the soil, especially from pearl millet residue. Silicon had the lowest release rate, with 62,82 and $74 \%$ of the total content in the shoot dry matter remaining in the last evaluation of pearl millet, pigeonpea and in the intercrop system, respectively. The shoot dry matter from the intercrop system had a different decomposition rate than that from the pearl millet monoculture and pigeonpea. Plants with greater shoot dry matter production and lower C/Si ratio are more effective in a no-tillage system for providing a more complete and persistent soil cover.
\end{abstract}

Index terms: Cajanus cajan, Pennisetum glaucum, intercropping, nutrient release.

(1) This research was supported by FAPESP (São Paulo Research Foundation). Received for publication on November $1^{\text {st }}, 2012$ and approved on July 31, 2013.

(2) Full Professor at the Department of Crop Science, College of Agricultural Sciences (FCA), São Paulo State University (UNESP). Rua José Barbosa de Barros, 1780. Fazenda Experimental Lageado. CEP 18610-307 Botucatu (SP), Brazil. Research award from CNPq. E-mail: crusciol@fca.unesp.br

(3) $\mathrm{PhD}$ student in Agronomy (Agriculture), FCA/UNESP. E-mail: jfneto@fca.unesp.br. chmcosta@fca.unesp.br

(4) Associate Professor at the Department of Crop Science, FCA/UNESP. Research award from CNPq. E-mail: soratto@fca.unesp.br 


\title{
RESUMO: CICLAGEM DE NUTRIENTES E SILÍCIO PELO GUANDU-ANÃO E MILHETO CULTIVADOS SOLTEIROS E CONSORCIADOS
}

\begin{abstract}
As características mais importantes na escolha de plantas de cobertura para o sistema plantio direto são a quantidade e a durabilidade da fitomassa produzida, bem como a capacidade de reciclar nutrientes. Este estudo objetivou avaliar a produção de fitomassa, taxa de decomposição e ciclagem de macronutrientes e silicio pelo guandu-anão e milheto, em cultivo solteiro e consorciado. O delineamento experimental foi em blocos casualizados, com quatro repetições, em esquema fatorial $3 \times 6$, constituido por três tipos de cobertura vegetal (guandu-anão, milheto e o consórcio dessas espécies) e seis épocas de coleta [0, 18, 32, 46, 74 e 91 dias, após a dessecação (DAD)]. O milheto produziu maior quantidade de fitomassa, acumulou mais $N, P, K, C a, M g, S, C$ e Si e teve maior taxa de decomposição e de liberação de macronutrientes e Si que as demais coberturas vegetais. As maiores taxas de decomposição e liberação diária de nutrientes das fitomassas ocorreram no primeiro período de avaliação (0 a $18 \mathrm{DAD}$ ). Com o passar do tempo ocorreu aumento das relações $\mathrm{C} / \mathrm{N}, \mathrm{C} / \mathrm{Pe} \mathrm{C} / \mathrm{S}$ e redução na relação $C /$ Si e na taxa de decomposição da fitomassa. $O K$ foi o nutriente mais rapidamente disponibilizado ao solo, especialmente pela fitomassa do milheto. O Si foi o elemento que teve a menor taxa de liberação, restando na última avaliação 62,82 e $74 \%$ do total acumulado na fitomassa, respectivamente de milheto, guandu-anão e consórcio. A taxa de decomposição da fitomassa do consórcio milheto e guandu-anão foi diferente da proveniente dos cultivos solteiros. Plantas com maior produção de fitomassa e com menor relação C/ Si são mais interessantes para utilização no SPD, por proporcionarem maior e mais persistente cobertura do solo.
\end{abstract}

Termos de indexação: Cajanus cajan, Pennisetum glaucum, consórcio, liberação de nutrientes.

\section{INTRODUCTION}

For the implementation and maintenance of a notillage system, a vegetation cover should be planted to keep the soil surface continuously covered with plant biomass and which can recycle nutrients and gradually make them available to successive crops. The persistence of shoot dry matter (SDM) on the soil, the nutrient recycling capacity, the mobilization of leached or not very soluble elements and their release to the subsequent crop are important indicators of the quality of cover crops (Boer et al., 2007; 2008; Crusciol \& Soratto, 2007; Carneiro et al., 2008; Crusciol et al., 2005; 2008; Leite et al., 2010). Thus, it is not easy to unite all the aforementioned qualities in a single species, which should also increase the diversification in crop rotations or intercropping, providing soil protection and nutrient recycling in the no-tillage planting system under different soil and climatic conditions.

In the grain-producing regions of Brazil, characterized by dry winters, the grass species pearl millet (Pennisetum glaucum (L.) R. Brown) is the most commonly used cover species (Boer et al., 2007). This crop is characterized by high SDM production and persistence on the soil after desiccation (Silva et al., 2010) and high soil nutrient extraction capacity, with additional advantages in nutrient recycling, especially $\mathrm{N}$ and $\mathrm{K}$, reducing the risk of losses through leaching (Crusciol \& Soratto, 2009).

Pigeonpea (Cajanus cajan (L.) Millsp.) is a legume, characterized by a lower $\mathrm{C} / \mathrm{N}$ ratio than pearl millet; the SDM persistence on the soil is shorter and it produces up to $6,000 \mathrm{~kg} \mathrm{ha}^{-1}$ (Torres et al., 2008).
However, it promotes nutrient recycling through nutrient uptake from deeper soil layers and adds $\mathrm{N}$ to the system by means of biological fixation (Teixeira et al., 2005; Salmi et al., 2006). In addition, Andrade et al. (2009) reported that soil macroporosity in the 0$10 \mathrm{~cm}$ layer was greater under pigeonpea than pearl millet. Therefore, this crop may be an option for growing in areas under a no-tillage with compaction problems in the upper soil layer.

With regard to the durability of SDM, plants with a low $\mathrm{C} / \mathrm{N}$ ratio may have a high residue decomposition rate, and plants with a high $\mathrm{C} / \mathrm{N}$ ratio may have a reduced decomposition rate and delayed nutrient release to the soil (Teixeira et al., 2009; Silva et al., 2012; Carvalho et al., 2013). Costa et al. (2012) reported that the $\mathrm{C} / \mathrm{N}, \mathrm{C} / \mathrm{P}, \mathrm{C} / \mathrm{S}$ and $\mathrm{C} / \mathrm{Si}$ ratios express the resistance of SDM to decomposition. Nevertheless, due to the scarcity of studies that relate the $\mathrm{C} / \mathrm{Si}$ ratio to SDM degradation in the soil, more studies are required to establish the importance of this relation to residue persistence. Silicon is considered a beneficial element to plants and has been associated with an increase in photosynthetic efficiency as a result of better light utilization, by stabilizing plants for more upright growth and reduction of water loss by transpiration. In addition, it can increase the mechanical resistance of cells and tolerance to pests and diseases (Lana et al., 2003; Gunes et al., 2007; Carré-Missio et al., 2010; Sousa et al., 2010).

In spite of the scarcity of studies on this issue in soil cover crops, it may be inferred that the aforementioned benefits of Si may have a positive effect on the production and persistence of the SDM of these plants on the soil, especially due to the increase in 
photosynthetic efficiency and mechanical resistance of cells. In general, grasses are considered to be siliconaccumulating plants while legumes are not and, according to Chagas (2004), the high variation of silicon concentration in plants occurs according to the physiology of the different species and to the environment in which they are grown. Thus, it is important to know the Si nutrition of the different species used as cover crops, such as pearl millet and pigeonpea, as well as the effect of the C/Si ratio of the cover crops on SDM persistence on the soil.

Intercropping of legumes and grasses is an attempt to unite the individual benefits of each species, to attenuate the problem of low SDM production and persistence, and of soil compaction and $\mathrm{N}$ deficiency in the initial stages of development of successive crops, as well as to recycle the nutrients with high mobility in the soil (Aita \& Giacomini, 2003; Perin et al., 2004; Teixeira et al., 2005; Calvo et al., 2010), notably N in the form of nitrate, and increase the supply of this nutrient in the soil by biological fixation by the legume. In addition, normally, the content of nutrients in the SDM, the speed of decomposition and nutrient release from these plants varies between grasses and legumes (Boer et al., 2007), which may also be an advantage in intercropping. Thus, the study of the dynamic of decomposition and release of macronutrients and silicon from the intercrop pearl millet and pigeonpea is extremely important as a basis for recommendation of this technique (Leite et al., 2010).

Given the above, the purpose was to evaluate the cycling of macronutrients, carbon and silicon by pigeonpea and pearl millet shoot dry matter in monoculture and intercropping, as well as the $\mathrm{C} / \mathrm{N}$, $\mathrm{C} / \mathrm{P}, \mathrm{C} / \mathrm{S}$ and $\mathrm{C} / \mathrm{Si}$ ratios.

\section{MATERIAL AND METHODS}

This study was developed at the Lageado Experimental Farm of the College of Agricultural Sciences (UNESP), Botucatu, São Paulo, Brazil $\left(22^{\circ} 58^{\prime} \mathrm{S}, 48^{\circ} 23^{\prime} \mathrm{W}, 765 \mathrm{~m}\right.$ asl), from October 2004 to March 2005 (2004/05 growing season). The soil at the location is a Red Nitosol and the chemical characteristics $(0-20 \mathrm{~cm})$ were determined prior to the experiment, as follows: $25.0 \mathrm{~g} \mathrm{dm}^{-3}$ organic matter; $\mathrm{pH}\left(\mathrm{CaCl}_{2}\right) 5.0 ; 17.0 \mathrm{mg} \mathrm{dm}^{-3} \mathrm{P}_{\text {resin }} ; 1.6,33.3,17.6$, $34.1 \mathrm{mmol}_{\mathrm{c}} \mathrm{dm}^{-3} \mathrm{~K}, \mathrm{Ca}, \mathrm{Mg}$ and $\mathrm{H}+\mathrm{Al}$, respectively; and $61 \%$ base saturation. With regard to textural classification, the soil is clayey with $512 \mathrm{~g} \mathrm{~kg}^{-1}$ clay, $381 \mathrm{~g} \mathrm{~kg}^{-1}$ sand and $107 \mathrm{~g} \mathrm{~kg}^{-1}$ silt.

According to the Köppen climate classification, the predominant climate in the region is $\mathrm{Cwa}$, i.e., a higher altitude tropical climate with dry winters and hot, wet summers. Reference data for average monthly temperature and total monthly rainfall throughout the experimental period are shown in figure 1 .

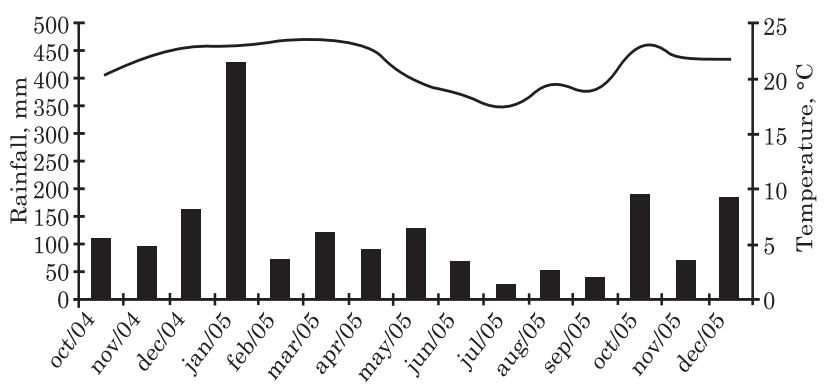

Figure 1. Total monthly rainfall () and average monthly temperature (-) in the period of conducting the experiment.

A randomized block experimental design was used with four replications in a $3 \times 6$ factorial arrangement, consisting of three cover plants (pigeonpea, pearl millet and pigeonpea + pearl millet) and six samplings of shoot dry matter $[0,18,32,46,74$ and 91 days after desiccation (DAD)]. The plot size was $75 \mathrm{~m}^{2}$ (width $5 \mathrm{~m}$, length $15 \mathrm{~m}$ ).

The cover species were sown on October 21, 2004, and seedlings emerged nine days later October 30, 2004. A seed quantity of 40, 20 and $20+10 \mathrm{~kg} \mathrm{ha}^{-1}$ was used of pigeonpea (Cajanus cajan L.), pearl millet (Pennisetum glaucum (L.) R. Brown) and pigeonpea + pearl millet, respectively, with a spacing of $0.17 \mathrm{~m}$ between rows and a depth of approximately $0.05 \mathrm{~m}$. At the time of flowering of the species, 75 days after emergence (DAE), on April 14, 2005, the crops were desiccated with glyphosate herbicide (1,920 $\mathrm{g} \mathrm{ha}^{-1}$ a.i.).

The biomass of the plants above the soil surface were collected (0 DAD), on February 1st, 2005 (18DAD), on 02/15/2005 (32 DAD), on 03/01/2005 (46 DAD), on 03/29/2005 (74 DAD) and on 04/15/2005 (91 DAD). Three plots were sampled on each date according to the method proposed by Crusciol et al. (2005), from an internal area of $0.25 \mathrm{~m}^{2}$ (simple samples), constituting one compound sample per plot. Within the experimental units, sampling was performed at random points along diagonal crosswise lines, excluding $0.50 \mathrm{~m}$ at either end (border).

The plant residues were pre-cleaned for removal of larger soil particles. Then they were washed according to the methods of Malavolta et al. (1997), although modified, i.e., without detergent. Thus, the samples were separated in three portions, shaken for a few seconds in deionized water and then placed on paper towel. It should be noted that not using detergent reduced the exposure time to shaking in water and the number of successive portions, which reduced the probable $\mathrm{K}$ losses from shoot dry matter (SDM) as much as possible (Rosolem et al., 2003). The samples were placed in plastic bags and dried in a forced air circulation oven at $65^{\circ} \mathrm{C}$ to constant weight and then weighed for determination of SDM. The material was ground in a Willey mill for determination of the levels of macronutrients (Malavolta et al., 1997), carbon (Tedesco et al., 1995), and silicon (Korndörfer et al., 2002). 
The content of macronutrients, $\mathrm{C}$ and $\mathrm{Si}$ in the SDM was determined by the product of the amount of SDM by the concentration of the elements of the plant residue of each sampling. With these values, the degradation of SDM and the content of elements contained in it were calculated, and the data were expressed in $\mathrm{kg} \mathrm{ha}^{-1}$. This result was also expressed in percentage (\%) by the calculation: remaining content of SDM or of each nutrient from the initial content in each time period, multiplied by 100 .

To describe SDM decomposition and the remaining content of the elements (N, P, K, Ca, Mg, S, C, and $\mathrm{Si}$ ) in it, both in $\mathrm{kg} \mathrm{ha}^{-1}$ and in \%, the exponential mathematical model described by Thomas \& Asakawa (1993) of the $\mathrm{x}=\mathrm{x}_{0} \mathrm{e}^{-\mathrm{kt}}$ type was used, in which $\mathrm{x}$ is the content of SDM or of elements remaining after a period of time $t$, in days; $x_{0}$ is the initial quantity of $\mathrm{SDM}$ or of elements; and $\mathrm{k}$ is the constant of residue decomposition or release of elements. With the k value, the half-life time was calculated $\left(\mathrm{t}^{1} 1 / 2=0.693 / \mathrm{k}\right)(\mathrm{Paul}$ \& Clark, 1989), which expresses the period of time necessary for half of the plant residue to decompose or for half the elements contained in the SDM to be released. Applying the derivative first to the functions fitted to the data on SDM and content release of the elements, the daily rates of SDM decomposition and release of elements after cover crop desiccation were calculated (Rosolem et al., 2003; Kliemann et al., 2006).

The data were initially tested with regard to the normality of error distribution (Lilliefors test/SAEG 5.0) and the homogeneity of their variances (Cochran and Bartlett tests/SAEG 5.0), to check if they met the requirements for analysis of variance (Table 1 ). The mean values of the treatments of the factor plant cover type were compared by the Tukey test at $5 \%$ and the other data from the factor SDM were fitted to mathematical functions at $5 \%$.

\section{RESULTS AND DISCUSSION}

Shoot dry matter (SDM) production 75 DAE was $4,720,14,040$ and $6,195 \mathrm{~kg} \mathrm{ha}^{-1}$, for pigeonpea, pearl millet and intercrop, respectively (Figure 2a). Intercropping increased the shoot dry matter production by $31.3 \%$ over pigeonpea monoculture; however, it represented only $44 \%$ of the SDM production of pearl millet monoculture. There was apparently some competition between pigeonpea and pearl millet, limiting the growth of the grass. This may have occurred due to the sowing density of pigeonpea. In our study, half the density of each one of the species individually was used, which may however have not been the ideal proportion. Still, this is the proportion seed companies recommend when using intercropping, however, without a scientific basis in the literature, e.g., in a study of Calvo et al. (2010), who did not mention the sowing density of the intercropping of the two species, indicating a gap in this line of research.

Calvo et al. (2010) reported a shoot dry matter production of 1,397 and $7,631 \mathrm{~kg} \mathrm{ha}^{-1}$ of pigeonpea and of pigeonpea-pearl millet intercrop, respectively, 60 days after sowing, grown from March to July on a dystroferric Red Nitosol, in a conventional soil tillage system and with fertilization at planting of $200 \mathrm{~kg} \mathrm{ha}^{-1}$ of N-P-K fertilizer 08-28-16. In regard to pearl millet, SDM production in this study was greater than the yields achieved by Boer et al. $(2007,2008)$ and Cazetta et al. (2005), which were 10,801 and $10,673 \mathrm{~kg} \mathrm{ha}^{-1} 51$ days after sowing and $60 \mathrm{DAE}$, respectively. It should be noted that Boer et al. (2007, 2008) sowed pearl millet in April on a dystroferric Red Oxisol with fertilization at sowing of $250 \mathrm{~kg} \mathrm{ha}^{-1}$ of the N-P-K fertilizer 08-28-16. Cazetta et al. (2005) performed no-tillage sowing of pearl millet in September on a dystrophic Red Oxisol, with no fertilization at sowing. Thus, the climate conditions of the different sowing seasons and of soil, crop and fertilization management were the main factors related to SDM production.

The rates of SDM decomposition of the cover crops were highest from 0 to $18 \mathrm{DAD}$, reaching values of 221,54 and $74 \mathrm{~kg} \mathrm{ha}^{-1}$ day $^{-1}$, in pearl millet, pigeonpea and intercrop, respectively (Table 2). Thus, $50 \%$ of the initial quantity of pearl millet SDM had been decomposed $37 \mathrm{DAD}$, and $50 \%$ of the SDM of pigeonpea and intercrop had been decomposed only 56 and 52 DAD, respectively (Figure 2a,b). This higher decomposition rate of pearl millet is due to the high quantity of structures subject to decomposition in comparison to the other soil cover crops. Nevertheless, in spite of being less persistent, the quantity of pearl millet SDM on the soil was statistically equal to that of the other cover crops 91 DAD (Figure 2a).

The values of the $\mathrm{C} / \mathrm{N}, \mathrm{C} / \mathrm{P}$ and $\mathrm{C} / \mathrm{S}$ ratios express the durability of the plant residue, and over the course of time and as the nutrients N, P and S were released, these ratios increased (Soratto et al., 2012) (Figure $2 \mathrm{c}, \mathrm{d}, \mathrm{e})$. Thus, at the time of desiccation, the ratios $\mathrm{C} / \mathrm{N}, \mathrm{C} / \mathrm{P}$ and $\mathrm{C} / \mathrm{S}$ of the shoot dry matter were 26 , 176 and 187 for pearl millet, 19, 204 and 350 for pigeonpea, and 33, 214 and 219 for the intercrop, respectively. In the last sampling, the values of these ratios were 43,305 and 527 for pearl millet, 32,283 and 798 for pigeonpea and 48, 342 and 822 for the intercrop, respectively (Figure 2c,d,e). Costa et al. (2012) also observed an increase in the $\mathrm{C} / \mathrm{N}, \mathrm{C} / \mathrm{P}$ and $\mathrm{C} / \mathrm{S}$ ratios, and reduction in the $\mathrm{C} / \mathrm{Si}$ ratio over time in crotalaria SDM.

In spite of not differing statistically, the straw residue from intercropping had a greater numerical value of $\mathrm{C} / \mathrm{N}$ ratio than the residues from pigeonpea and pearl millet monoculture (Figure 2). This is noteworthy since, hypothetically, intercropping would have an intermediate value of the $\mathrm{C} / \mathrm{N}$ ratio. $\mathrm{A}$ probable explanation is a reduced development of 
Table 1. Analysis of variance for variables related to shoot dry matter (SDM), ratios between carbon, nutrients and $\mathrm{Si}$, nutrient and $\mathrm{Si}$ concentration and content of nutrients and Si remaining in the monoculture and intercrop pigeonpea and pearl millet shoot dry matter (SDM) according to soil cover (C) and days after desiccation (DAD)

\begin{tabular}{|c|c|c|c|c|}
\hline \multirow{2}{*}{ Variable } & \multicolumn{3}{|c|}{ F Value } & \multirow{2}{*}{ CV $(\%$} \\
\hline & Soil cover $(\mathrm{C})$ & DAD (D) & C $\times$ D & \\
\hline $\operatorname{SDM}\left(\mathrm{kg} \mathrm{ha}^{-1}\right)$ & $263.286^{* *}$ & $188.336^{* *}$ & $31.414^{* *}$ & 13.3 \\
\hline C/N Ratio & $23.469^{* *}$ & $5.292^{* *}$ & $0.220 \mathrm{~ns}$ & 22.3 \\
\hline C/P Ratio & $5.700^{* * *}$ & $6.882^{* *}$ & $0.639 \mathrm{~ns}$ & 20.5 \\
\hline C/S Ratio & $15.853^{* *}$ & $42.545^{* *}$ & $2.249^{*}$ & 19.3 \\
\hline C/Si Ratio & $191.643^{* *}$ & $43.133^{* *}$ & $4.604^{* *}$ & 22.2 \\
\hline $\mathrm{N}\left(\mathrm{g} \mathrm{kg}^{-1}\right)$ & $35.458^{* *}$ & $15.370^{* *}$ & $0.699 \mathrm{~ns}$ & 23.3 \\
\hline $\mathrm{P}\left(\mathrm{g} \mathrm{kg}^{-1}\right)$ & $12.573^{* *}$ & $15.444^{* *}$ & $0.772 \mathrm{~ns}$ & 19.8 \\
\hline $\mathrm{K}\left(\mathrm{g} \mathrm{kg}^{-1}\right)$ & $0.440 \mathrm{~ns}$ & $314.574^{* *}$ & $28.479 * *$ & 19.4 \\
\hline $\mathrm{Ca}\left(\mathrm{g} \mathrm{kg}^{-1}\right)$ & $110.127^{* * *}$ & $19.569 * *$ & $3.034^{* *}$ & 17.0 \\
\hline $\mathrm{Mg}\left(\mathrm{g} \mathrm{kg}^{-1}\right)$ & $90.397^{* *}$ & $40.803^{* *}$ & $3.541^{* *}$ & 14.0 \\
\hline $\mathrm{S}\left(\mathrm{g} \mathrm{kg}^{-1}\right)$ & $17.110^{* *}$ & $82.951 * *$ & $4.333^{* *}$ & 15.6 \\
\hline $\mathrm{C}\left(\mathrm{g} \mathrm{kg}^{-1}\right)$ & $7.163^{* *}$ & $11.094^{* *}$ & $0.681 \mathrm{~ns}$ & 6.9 \\
\hline $\mathrm{Si}\left(\mathrm{g} \mathrm{kg}^{-1}\right)$ & $151.663^{* *}$ & $50.147^{* * *}$ & $4.501^{* *}$ & 22.2 \\
\hline $\mathrm{N}\left(\mathrm{kg} \mathrm{ha}^{-1}\right)$ & $46.196^{* *}$ & $89.906^{* *}$ & $9.650^{* *}$ & 28.8 \\
\hline $\mathrm{P}\left(\mathrm{kg} \mathrm{ha}^{-1}\right)$ & $44.154^{* *}$ & $67.937^{* *}$ & $13.597^{* *}$ & 32.2 \\
\hline $\mathrm{K}\left(\mathrm{kg} \mathrm{ha}^{-1}\right)$ & $167.960 * *$ & $505.796^{* *}$ & $140.138^{* *}$ & 23.0 \\
\hline $\mathrm{Ca}\left(\mathrm{kg} \mathrm{ha}^{-1}\right)$ & $21.995^{* *}$ & $153.371^{* *}$ & $6.268^{* *}$ & 19.4 \\
\hline $\mathrm{Mg}\left(\mathrm{kg} \mathrm{ha}^{-1}\right)$ & $300.062^{* *}$ & $163.714^{* *}$ & $43.699^{* *}$ & 20.7 \\
\hline $\mathrm{S}\left(\mathrm{kg} \mathrm{ha}^{-1}\right)$ & $139.413^{* *}$ & $167.302^{* *}$ & $38.537^{* *}$ & 25.2 \\
\hline $\mathrm{C}\left(\mathrm{kg} \mathrm{ha}^{-1}\right)$ & $198.054^{* *}$ & $197.682^{* *}$ & $26.930 * *$ & 14.3 \\
\hline $\mathrm{Si}\left(\mathrm{kg} \mathrm{ha}^{-1}\right)$ & $506.453^{* *}$ & $11.287^{* *}$ & $7.027^{* *}$ & 26.5 \\
\hline
\end{tabular}

ns: not significant; ${ }^{*} \mathrm{p} \leq 0.05 ;{ }^{* *} \mathrm{p} \leq 0.01$.

pigeonpea leaves due to the competition between the two species, as visually observed. The leaf structures have a greater $\mathrm{N}$ content and, consequently, a lower $\mathrm{C} / \mathrm{N}$ ratio than the stem.

At the time of desiccation, the values of the $\mathrm{C} / \mathrm{Si}$ ratio were 16, 45 and 19 for pearl millet, pigeonpea and intercrop SDM, respectively (Figure 2f). At the last sampling (91 DAD), the values of this relation were 5, 17 and 6 for pearl millet, pigeonpea and intercrop, respectively. Silicon may be related to the more recalcitrant plant structures, and, for that reason, the C/Si ratio decreased over time. As the SDM decomposes, the portion of these structures of plant tissues that are not easily degraded increases, reducing the decomposition rate. Nevertheless, it may be deduced that, similarly to the other ratios, the $\mathrm{C} /$ Si ratio is also important in studies of SDM decomposition (Costa et al., 2012).

At the time of desiccation, the N, P, K, Ca, Mg, S, $\mathrm{C}$, and Si concentrations of pigeonpea SDM were 28, $2.6,11,8.3,2,1.5,514$, and $11.5 \mathrm{~g} \mathrm{~kg}^{-1}$; of intercrop $16,2.2,19,7,2.5,2,478$, and $25 \mathrm{~g} \mathrm{~kg}^{-1}$; and of pearl millet 18, 2.7, 23, 4, 3.4, 2.5, 460, and 29.4, respectively (Figure 3). Teixeira et al. (2005) observed lower values of $\mathrm{N}, \mathrm{P}, \mathrm{K}, \mathrm{Ca}, \mathrm{Mg}$, and $\mathrm{S}$ in pigeonpea and pearl millet SDM in monoculture. In the intercrop of these species, the authors obtained values near those found in this study. Nevertheless, it is important to highlight that the soil and climatic conditions were different since the authors mentioned above conducted the experiment in a dystroferric Red Oxisol from March to July.

Comparing the nutrient concentrations observed 75 DAE with those obtained by Cazetta et al. (2005) 60 DAE, it was observed that the $\mathrm{N}$ and $\mathrm{K}$ concentrations of pearl millet SDM were approximately 8.5 and $9.0 \mathrm{~g} \mathrm{~kg}^{-1}$, less and greater, respectively. The differences in these concentrations may be explained by the different growing seasons and by factors related to the soil fertility of each location. As reported by Teixeira et al. (2005), the variability in nutrient concentrations within the same species is mostly due to differences in the soil fertility of the study locations. The concentration of all macronutrients declined over time, accompanying the results of the SDM (Figures 2a and 3), with the exception of Si. Thus, as the SDM degraded, the Si concentration in the plant residue increased because the more soluble elements were released (Figure 3) with the remaining Si compounds, which have lower solubility (Fernandez et al., 2009). 

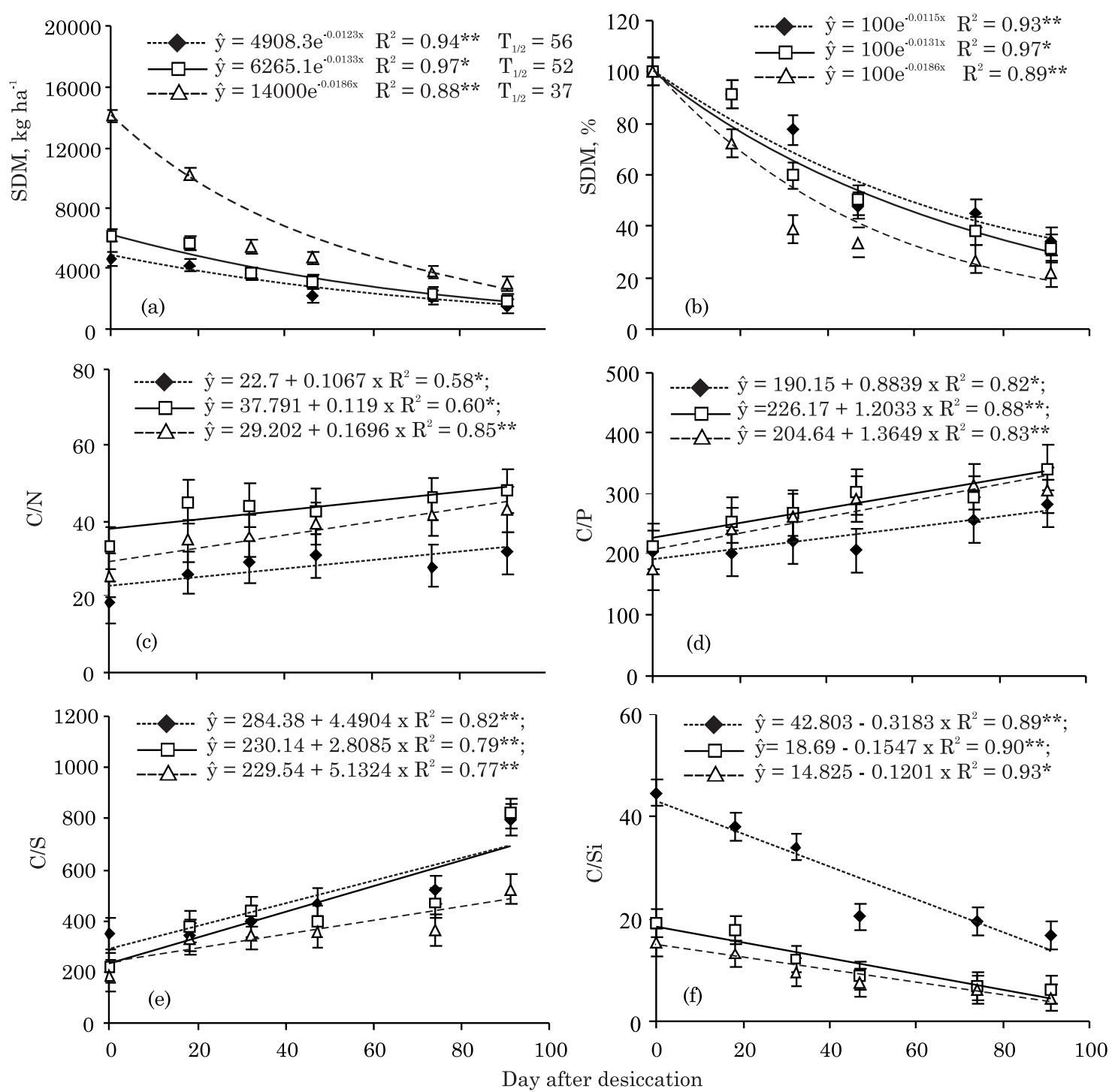

Figure 2. Shoot dry matter - SDM (a), percentage of plant dry shoot dry matter (b), C/N (c), C/P (d), C/S (e) and C/Si (f) ratios of pigeonpea ( - - - ), pigeonpea+pearl millet ( $\square-)$ and pearl millet (-- $\triangle--)$ shoot dry matter according to time after desiccation. $* *$ and $*$ significant at 1 and $5 \%$ by the $\mathrm{F}$ test. $\mathrm{T}_{1 / 2}$ refers to the half-life time in DAD. Vertical bars indicate the value of LSD at $5 \%$ by the Tukey test.

Greater $\mathrm{N}$ and Ca concentration in pigeonpea SDM, greater $\mathrm{Mg}$ concentration in pearl millet SDM and the large reduction of $\mathrm{K}$ concentrations in the three plant SDM were evident (Figure 3a,c,d). Teixeira et al. (2005), studying SDM production and macronutrient concentration in pearl millet, jack bean and pigeonpea, in monoculture and intercropping, also observed greater $\mathrm{N}$ and $\mathrm{Ca}$ concentrations in the legumes.

The greater $\mathrm{N}$ concentration observed in pigeonpea can be explained by the symbiosis of pigeonpea with specific bacteria which fix atmospheric $\mathrm{N}_{2}$. Reductions in the K concentrations of pigeonpea ( $77 \%$ ), intercrop (95\%) and pearl millet (96\%) SDM, observed 91 DAD (Figure 3c), arose from the dissociation of the element from the structure of the plant tissue (Marschner, 2012). This element is not metabolized in the plant and forms bonds with easily reversible organic complexes (Rosolem et al., 2003). Thus, as the aboveground part of the plants begins the drying process and degrades, the concentration of $\mathrm{K}$ in the tissue decreases drastically because it is easily carried away by rainwater (Khatounian, 1999) after rupture of the plasmatic membrane (Malavolta et al., 1997). The rapid release of $\mathrm{K}$ from the SDM was also observed by Crusciol et al. (2005, 2008) in oilseed radish and black oats, and by Boer et al. (2007) and Leite et al. (2010) in pearl millet.

The contents of N, P, K, Ca, Mg, S, C, and Si in the SDM at the time of pigeonpea desiccation were $135,12,51,38,10,7,2434$, and $54 \mathrm{~kg} \mathrm{ha}^{-1}$, for the intercrop 100,14,120,41,15,14, 2970, and $157 \mathrm{~kg}$ $\mathrm{ha}^{-1}$, and for pearl millet $257,39,322,57,48,35$, 
Table 2. Rates of decomposition and daily releases of $\mathrm{N}, \mathrm{P}, \mathrm{K}, \mathrm{Ca}, \mathrm{Mg}, \mathrm{S}, \mathrm{C}$ and $\mathrm{Si}$ of pigeonpea, intercrop pigeonpea+pearl millet and pearl millet shoot dry matter according to days after desiccation (DAD)

\begin{tabular}{|c|c|c|c|c|c|}
\hline \multirow{2}{*}{ Plant cover } & \multicolumn{5}{|c|}{ Interval } \\
\hline & 0-18 DAD & 19-32 DAD & 33-46 DAD & 47-74 DAD & 75-91 DAD \\
\hline & \multicolumn{5}{|c|}{ Dry matter $\left(\mathrm{kg} \mathrm{ha}^{-1}\right.$ day $\left.^{-1}\right)$} \\
\hline Pigeonpea & 54 & 44 & 37 & 29 & 22 \\
\hline Pigeonpea + millet & 74 & 60 & 50 & 38 & 28 \\
\hline \multirow[t]{2}{*}{ Pearl millet } & 221 & 164 & 126 & 86 & 56 \\
\hline & \multicolumn{5}{|c|}{$\mathrm{N}\left(\mathrm{kg} \mathrm{ha}{ }^{-1}\right.$ day $\left.^{-1}\right)$} \\
\hline Pigeonpea & 1.74 & 1.30 & 0.10 & 0.69 & 0.46 \\
\hline Pigeonpea+millet & 1.38 & 1.01 & 0.77 & 0.52 & 0.34 \\
\hline \multirow[t]{2}{*}{ Pearl millet } & 5.48 & 3.55 & 2.41 & 1.39 & 0.76 \\
\hline & \multicolumn{5}{|c|}{$\mathrm{P}\left(\mathrm{kg} \mathrm{ha}^{-1}\right.$ day $\left.^{-1}\right)$} \\
\hline Pigeonpea & 0.19 & 0.14 & 0.11 & 0.08 & 0.05 \\
\hline Pigeonpea + millet & 0.23 & 0.16 & 0.12 & 0.08 & 0.05 \\
\hline \multirow[t]{2}{*}{ Pearl millet } & 0.87 & 0.55 & 0.36 & 0.20 & 0.11 \\
\hline & \multicolumn{5}{|c|}{$\mathrm{K}\left(\mathrm{kg} \mathrm{ha}{ }^{-1}\right.$ day $\left.^{-1}\right)$} \\
\hline Pigeonpea & 1.14 & 0.73 & 0.50 & 0.29 & 0.15 \\
\hline Pigeonpea+millet & 3.09 & 1.40 & 0.70 & 0.26 & 0.09 \\
\hline \multirow[t]{2}{*}{ Pearl millet } & 11.99 & 4.39 & 1.80 & 0.53 & 0.13 \\
\hline & \multicolumn{5}{|c|}{$\mathrm{Ca}\left(\mathrm{kg} \mathrm{ha} \mathrm{H}^{-1}\right.$ day $\left.^{-1}\right)$} \\
\hline Pigeonpea & 0.66 & 0.49 & 0.37 & 0.25 & 0.17 \\
\hline Pigeonpea + millet & 0.55 & 0.40 & 0.30 & 0.20 & 0.13 \\
\hline \multirow[t]{2}{*}{ Pearl millet } & 1.08 & 0.75 & 0.53 & 0.33 & 0.20 \\
\hline & \multicolumn{5}{|c|}{$\operatorname{Mg}\left(\mathrm{kg} \mathrm{ha}^{-1} \mathrm{day}^{-1}\right)$} \\
\hline Pigeonpea & 0.15 & 0.11 & 0.08 & 0.06 & 0.04 \\
\hline Pigeonpea + millet & 0.27 & 0.19 & 0.14 & 0.09 & 0.06 \\
\hline \multirow[t]{2}{*}{ Pearl millet } & 1.02 & 0.66 & 0.45 & 0.26 & 0.14 \\
\hline & \multicolumn{5}{|c|}{$\mathrm{S}\left(\mathrm{kg} \mathrm{ha}^{-1} \mathrm{day}^{-1}\right)$} \\
\hline Pigeonpea & 0.14 & 0.010 & 0.07 & 0.05 & 0.03 \\
\hline Pigeonpea + millet & 0.25 & 0.16 & 0.11 & 0.06 & 0.04 \\
\hline \multirow[t]{2}{*}{ Pearl millet } & 0.85 & 0.51 & 0.32 & 0.17 & 0.08 \\
\hline & \multicolumn{5}{|c|}{$\mathrm{C}\left(\mathrm{kg} \mathrm{ha}^{-1}\right.$ day $\left.^{-1}\right)$} \\
\hline Pigeonpea & 29 & 23 & 19 & 15 & 11 \\
\hline Pigeonpea+millet & 41 & 32 & 25 & 18 & 13 \\
\hline \multirow[t]{2}{*}{ Pearl millet } & 109 & 79 & 59 & 39 & 25 \\
\hline & \multicolumn{5}{|c|}{ Si $\left(\mathrm{kg} \mathrm{ha}^{-1}\right.$ day $\left.^{-1}\right)$} \\
\hline Pigeonpea & 0.12 & 0.12 & 0.12 & 0.12 & 0.12 \\
\hline Pigeonpea + millet & 0.41 & 0.41 & 0.41 & 0.41 & 0.41 \\
\hline Pearl millet & 4.67 & 3.34 & 2.14 & 0.39 & 0.00 \\
\hline
\end{tabular}

6459, and $412 \mathrm{~kg} \mathrm{ha}^{-1}$, respectively (Figure 4). These results show the high nutrient cycling capacity of pearl millet due to its large SDM production.

The contents of macronutrients in the three cover crops were greater than those observed by Teixeira et al. (2005). These authors evaluated the same cover crops, grown in the period from March to July, and assessed 119 days after sowing, and reported contents of $\mathrm{N}, \mathrm{P}, \mathrm{K}, \mathrm{Ca}, \mathrm{Mg}$, and $\mathrm{S}$ of $17,1.6,8,6$, 0.6 , and $0.9 \mathrm{~kg} \mathrm{ha}^{-1}$ in pigeonpea, of $52,6,44,10,4.3$, and $4.8 \mathrm{~kg} \mathrm{ha}^{-1}$ in the intercrop, and of $49,7,51,11$, 5 , and $4 \mathrm{~kg} \mathrm{ha}^{-1}$ in pearl millet, respectively.
The value of $\mathrm{N}$ accumulated by the SDM from intercropping (pigeonpea + pearl millet) at the time of desiccation was similar to that obtained by Calvo et al. (2010), who applied $200 \mathrm{~kg} \mathrm{ha}^{-1}$ of the N-P-K fertilizer 08-28-16 at planting and, similarly to Teixeira et al. (2005), grew the cover crops in the period from March to July, showing the importance of studies under different growth, soil and climate conditions.

In regard to $\mathrm{Si}$, in the last evaluation, the SDM of pigeonpea, intercrop and pearl millet, respectively still contained 44, 112 and $256 \mathrm{~kg} \mathrm{ha}^{-1}$. Therefore, 10, 45 

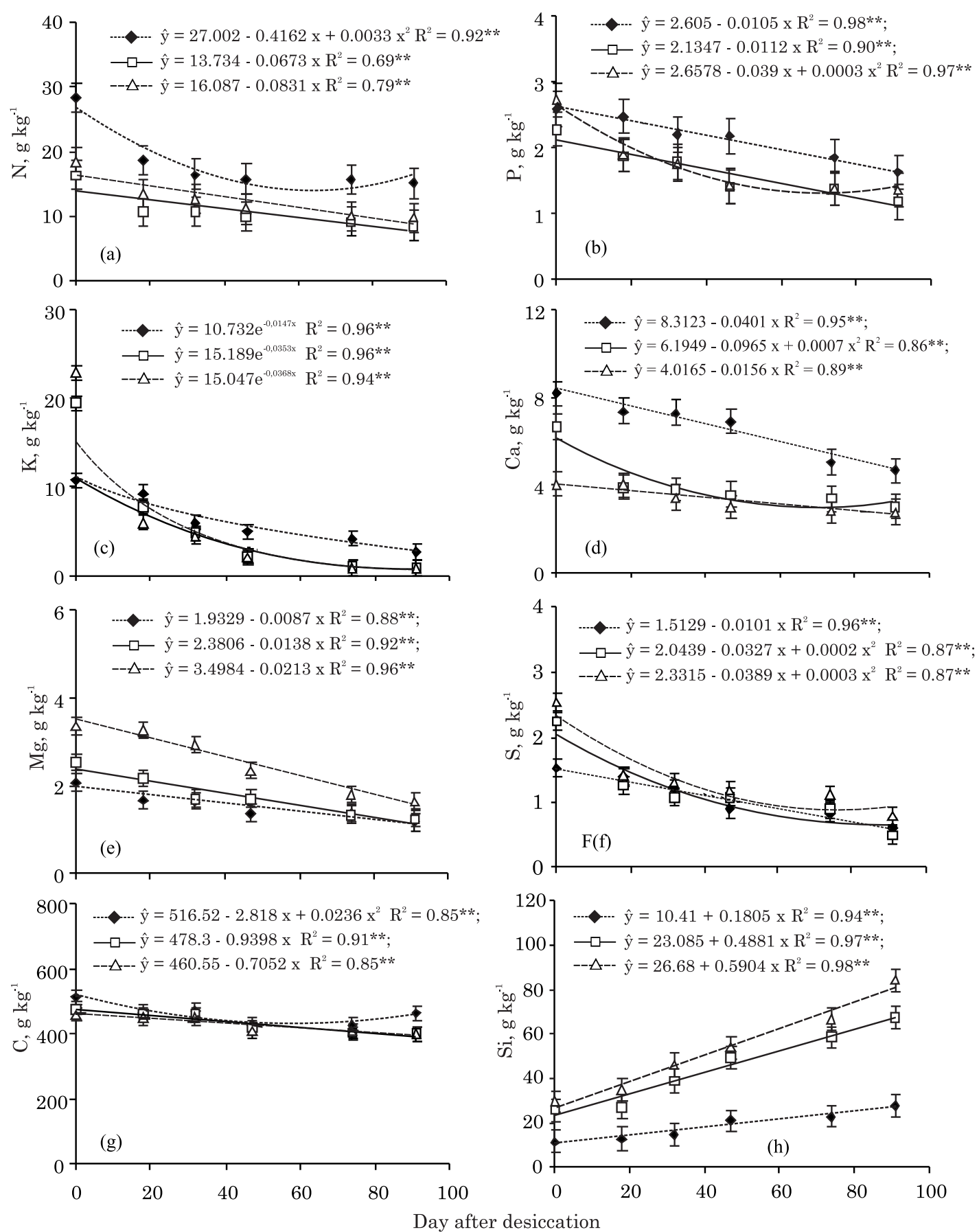

Figure 3. N (A), P (B), K (C), Ca (D), Mg (E), S (F), C (G) and Si (H) concentration of pigeonpea $(\ldots \rightarrow \cdots)$, pigeonpea+pearl millet ( $\square-$ ) and pearl millet (-- $\triangle--)$ shoot dry matter according to time after desiccation.*** significant at $1 \%$ by the F test. Vertical bars indicate the value of LSD at $5 \%$ by the Tukey test.

and $156 \mathrm{~kg} \mathrm{ha}^{-1}$ had been released to the soil, respectively (Figure $4 \mathrm{~h}$ ). There was greater accumulation in pearl millet shoot dry matter because grasses are considered to be Si-accumulating plants (Korndörfer et al., 2002).

The release of the macronutrients $\mathrm{N}, \mathrm{P}, \mathrm{K}, \mathrm{Ca}$, $\mathrm{Mg}$, and $\mathrm{C}$ from SDM was high over time, but most intense in pearl millet (Figure 4). In the last evaluation, $\mathrm{N}, \mathrm{P}, \mathrm{K}, \mathrm{Ca}, \mathrm{Mg}, \mathrm{S}$, and $\mathrm{C}$ had been released at amounts of $135,9,47,31,8,6$, and 1696 $\mathrm{kg} \mathrm{ha}^{-1}$ from pigeonpea SDM, 84, 12, 118, 35, 14, 13, and $2181 \mathrm{~kg} \mathrm{ha}^{-1}$ from the intercrop SDM, and 227 , $35,320,48,43,32$, and $5245 \mathrm{~kg} \mathrm{ha}^{-1}$ from pearl millet SDM, respectively.

It is noteworthy that the greater accumulation and availability of nutrients from pearl millet is directly 

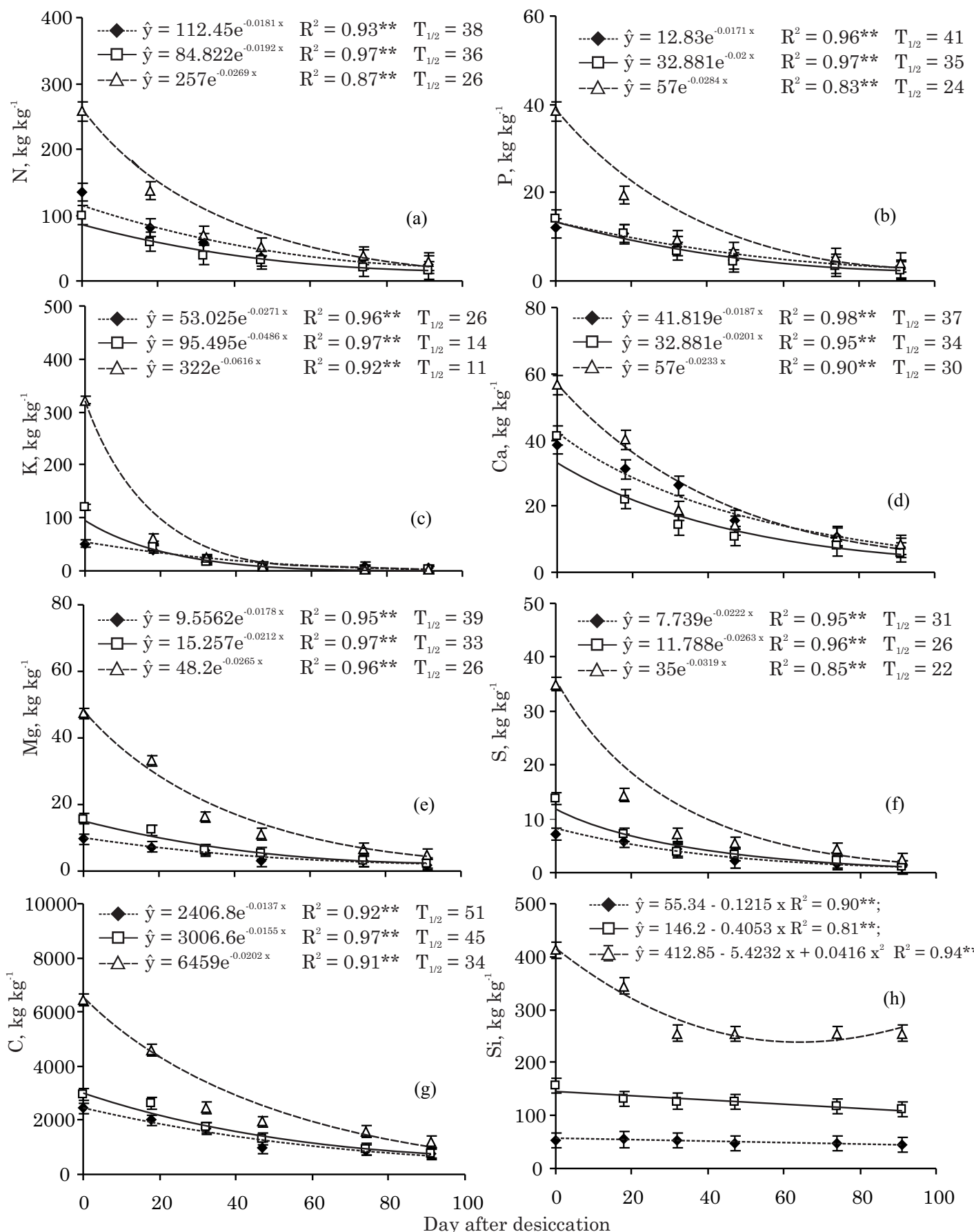

Figure 4. Content remaining of $\mathrm{N}(\mathrm{a}), \mathrm{P}(\mathrm{b}), \mathrm{K}(\mathrm{c}), \mathrm{Ca}(\mathrm{d}), \mathrm{Mg}(\mathrm{e}), \mathrm{S}(\mathrm{f}), \mathrm{C}(\mathrm{g})$ and $\mathrm{Si}(\mathrm{H})$ in pigeonpea (.......), pigeonpea+pearl millet $(-\square-)$ and pearl millet (-- --$)$ shoot dry matter according to time after desiccation.** significant at $1 \%$ by the $\mathrm{F}$ test. $\mathrm{T}_{1 / 2}$ refers to the half-life time in DAD. Vertical bars indicate the value of LSD at $5 \%$ by the Tukey test.

related to the high SDM production and to the higher decomposition rate of this species (Figure 2a, Table 2).

In terms of NPK fertilization, $91 \mathrm{DAD}$, the nutrient amount of pigeonpea SDM was equivalent to that in response to the fertilizers urea, simple superphosphate and potassium chloride $\left(252,113\right.$ and $91 \mathrm{~kg} \mathrm{ha}^{-1}$, respectively), whereas the intercrop SDM were 191,
145 and $245 \mathrm{~kg} \mathrm{ha}^{-1}$, and 516, 438 and $663 \mathrm{~kg} \mathrm{ha}^{-1}$ for pearl millet SDM.

In regard to $\mathrm{Si}$, in the last evaluation, there were still 44, 112 and $256 \mathrm{~kg} \mathrm{ha}^{-1}$ in pigeonpea, intercrop and pearl millet SDM, respectively. Therefore, 10, 45 and $156 \mathrm{~kg} \mathrm{ha}^{-1}$ had been released to the soil, respectively (Figure $4 \mathrm{~h}$ ). Thus, a considerable 

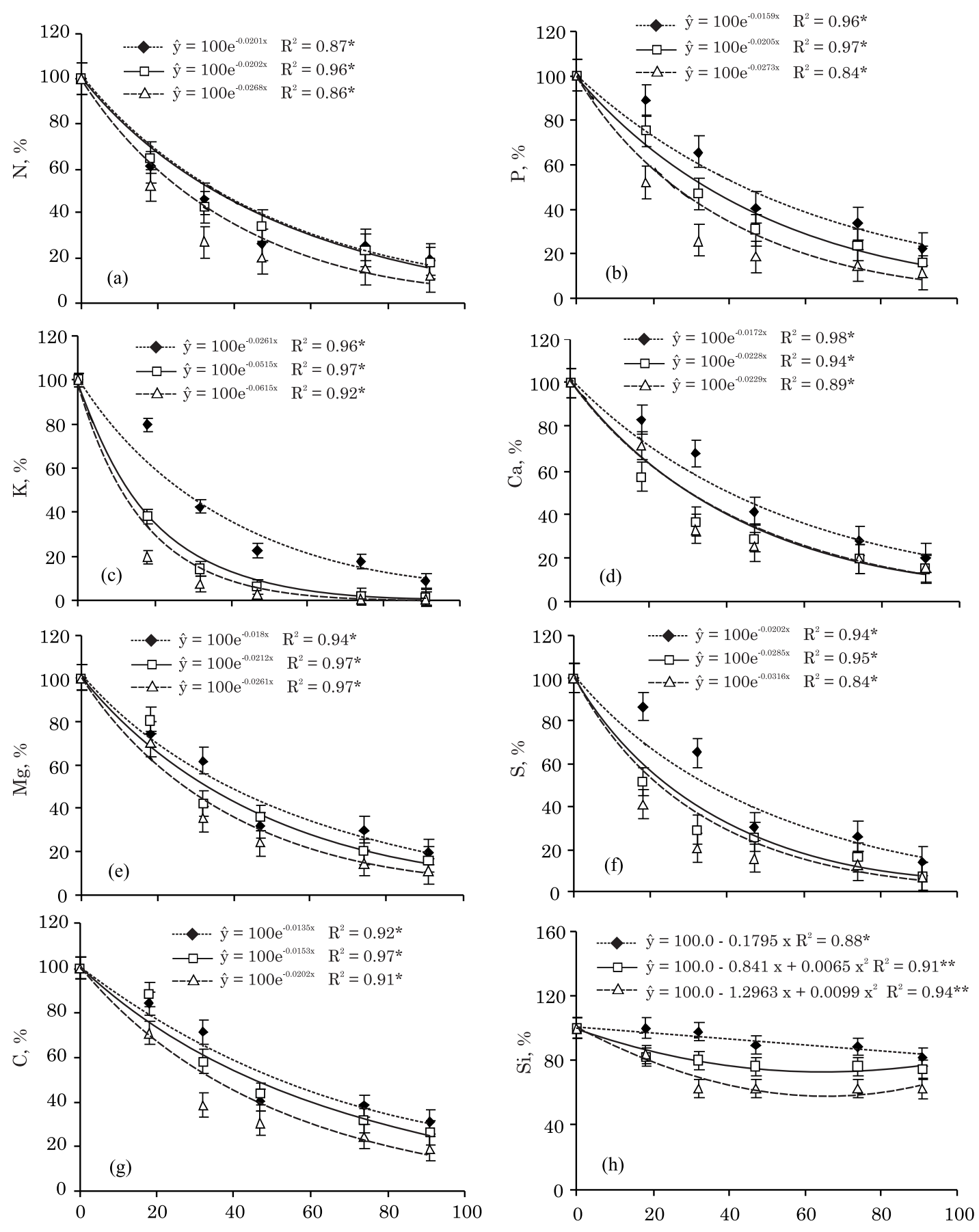

Figure 5. Percentages of N (a), P (b), K (c), Ca (d), Mg (e), S (f), C (g) and Si (h) in pigeonpea (-...), pigeonpea+pearl millet $(-\square-)$ and pearl millet $\left(--\triangle_{--)}\right.$shoot dry matter according to time after desiccation.** and * significant at 1 and $5 \%$ by the $\mathrm{F}$ test, respectively. Vertical bars indicate the value of LSD at $5 \%$ by the Tukey test.

accumulation was observed in the SDM of the three crop systems. However, there was a slow and gradual release from pigeonpea and intercrop, and more intense release from pearl millet, so that in the last evaluation 82,75 and $62 \%$ of the total Si quantity were still contained in the SDM of pigeonpea, intercrop and pearl millet, respectively (Figure 5h).
In terms of percentage, $91 \mathrm{DAD}, 81,78,91$, $80,80,86,69$ and $18 \%$ of pigeonpea SDM, 82,83 , $99,85,84,93,74$, and $25 \%$ of the intercrop SDM, and $88,88,99,84,89,93,81$, and $38 \%$ of pearl millet SDM in regard to $\mathrm{N}, \mathrm{P}, \mathrm{K}, \mathrm{Ca}, \mathrm{Mg}, \mathrm{S}, \mathrm{C}$, and Si had already been released, respectively (Figure 5). 
In addition to the contents, significant portions of nutrients were released, which may serve the need of crops in succession - $50 \%$ of the total contents $\mathrm{N}, \mathrm{P}$, $\mathrm{K}, \mathrm{Ca}, \mathrm{Mg}, \mathrm{S}$, and $\mathrm{C}$ had already been released from the SDM at 38, 41, 26, 37, 39, 31, and 51 DAD from pigeonpea, at $36,35,14,34,33,26$, and $45 \mathrm{DAD}$ from the intercrop, and at 26, 24, 11, 30, 26, 22, and 34 DAD from pearl millet, respectively (Figure 4a,b,c,d,e,f,g,). This shows that nutrient recycling and retention by cover crops and by green manure crops always minimize the risks of leaching losses (Aita et al., 1994). However, this can only be achieved if the cropping in the agricultural areas is continuous.

The maximum daily release of macronutrients occurred from 0 to $18 \mathrm{DAD}$ (Table 2). In this period, the daily release rates of $\mathrm{N}, \mathrm{P}, \mathrm{K}, \mathrm{Ca}, \mathrm{Mg}, \mathrm{S}$ and $\mathrm{C}$ from pigeonpea were $1.7,0.19,1.14,0.66,0.15,0.14$, and $29 \mathrm{~kg} \mathrm{ha}^{-1}$ day $^{-1}$, from pearl millet 5.48, 0.87, 11.99, $1.08,1.02,0.85$, and $109 \mathrm{~kg} \mathrm{ha}^{-1} \mathrm{day}^{-1}$ and from the intercrop 1.4, 0.23, 3.10, 0.55, 0.27, 0.25, and $41 \mathrm{~kg} \mathrm{ha}^{-1}$ day $^{-1}$, respectively. Thus, the macronutrient release in the period from 0 to $18 \mathrm{DAD}$ from pearl millet was highest because of the greater accumulation of these nutrients and the greater production and decomposition rate of the SDM of this cover crop (Table 2, Figures 2a and $4 a, b, c, d, e, f, g)$. In other words, there is a rapid release of the elements in the phase soon after desiccation, with a gradual reduction thereafter. Crusciol et al. (2008) evaluated the release rate of macronutrients from black oat shoot dry matter and also observed a greater release rate of $\mathrm{N}, \mathrm{K}, \mathrm{Ca}$, and $\mathrm{Mg}$ in the first $20 \mathrm{DAD}$. These authors grew black oats in the period from July to September on a eutroferric Red Oxisol and, despite the differences in the soil and climatic conditions and the soil cover crops of each study, the period of highest nutrient release rate was similar.

In regard to $\mathrm{Si}$, the maximum daily release from pearl millet shoot dry matter also occurred during the first evaluation period $\left(4.67 \mathrm{~kg} \mathrm{ha}^{-1} \mathrm{day}^{-1}\right)$. However, for pigeonpea and intercrop, the daily release rate was constant $\left(0.12\right.$ and $0.41 \mathrm{~kg} \mathrm{ha}^{-1} \mathrm{day}^{-1}$, respectively) (Table 2 ).

Since the daily release of macronutrients and $\mathrm{Si}$ was highest from 0 to $18 \mathrm{DAD}$, it is of utmost importance that the succeeding crop be planted soon after desiccation to take greater advantage of the recycled nutrients (Ferrari Neto et al., 2012).

In spite of pearl millet shoot dry matter being less persistent on the soil, the quantity produced offset the higher decomposition rate. The amount of SDM of this species on the soil was greater in most evaluations, and only 91 DAD amounts of SDM of the cover crops on the soil were similar. In addition, there was greater release of macronutrients and Si from pearl millet than from the other tested crops.

It was expected that intercropping would produce higher SDM at the time of desiccation than that which appeared (6195 $\left.\mathrm{kg} \mathrm{ha}^{-1}\right)$, with similar soil cover and nutrient cycling to pearl millet, but with greater accumulation and later release of $\mathrm{N}$ due to the $\mathrm{N}_{2}$ fixing symbiosis of pigeonpea. In this context, it was also expected that pigeonpea would make up for the lower production of its SDM in relation to pearl millet, with greater accumulation and release of N. However, these hypotheses were not confirmed.

Considering the results of this study, the cover crop most indicated for no-tillage systems in regions with dry winters is pearl millet, in view of the superior quality, with a more persistent soil cover and high macronutrient and Si cycling.

\section{CONCLUSIONS}

1. Pearl millet produced a greater amount of shoot dry matter and accumulated more N, P, K, Ca, Mg, S, $\mathrm{C}$, and $\mathrm{Si}$ than pigeonpea and pearl millet-pigeonpea intercrop.

2. The maximum daily release rate of macronutrients occurred soon after desiccation of the soil cover crops.

3 . The decomposition and release rate of the macronutrients and Si was greater in the shoot dry matter of pearl millet than of the other cover crops.

4. Potassium was the nutrient released to the soil most rapidly, especially through pearl millet straw.

5. Silicon was the element with the lowest release rate, with 62,82 and $74 \%$ of the total content remaining in the shoot dry matter in the last evaluation of pearl millet, pigeonpea and intercropping of both, respectively.

6. The shoot dry matter of intercrop pearl millet and pigeonpea had a different decomposition rate from residues from monoculture crops of these species.

7. Plants with greater shoot dry matter production and lower C/Si ratio are more suitable for use in notillage systems for providing a more complete and persistent soil cover.

\section{ACKNOWLEDGEMENTS}

The authors thank the São Paulo Research Foundation (FAPESP), for financial support (Registry number: 2004/10361-1), the National Council for Scientific and Technological Development (CNPq), for an award for excellence in research to the first and third authors, and Piraí Sementes, for seed donation.

\section{LITERATURE CITED}

AITA, C.; CERETTA, C.A.; THOMAS, A.L.; PAVINATO, A. \& BAYER, C. Espécies de inverno como fonte de nitrogênio para o milho no sistema de cultivo mínimo e feijão em plantio direto. R. Bras. Ci. Solo, 18:101-108, 1994. 
AITA, C. \& GIACOMINI, S.J. Decomposição e liberação de nitrogênio dos resíduos culturais de plantas de cobertura de solo solteiras e consorciadas. R. Bras. Ci. Solo, 27:601$612,2003$.

ANDRADE, R.S.; STONE, L.F. \& SILVEIRA, P.M. Culturas de cobertura e qualidade física de um Latossolo em plantio direto. R. Bras. Eng. Agríc. Amb., 13:411-418, 2009.

BOER, C.A.; ASSIS, R.L.; SILVA, G.P.; BRAZ, A.J.B.P.; BARROSO, A.L.L.; CARGNELUTTI FILHO, A. \& PIRES, F.R. Biomassa, decomposição e cobertura do solo ocasionada por resíduos culturais de três espécies vegetais na região centro-oeste do Brasil. R. Bras. Ci. Solo, 32:843$851,2008$.

BOER, C.A.; ASSIS, R.L.; SILVA, G.P.; BRAZ, A.J.B.P.; BARROSO, A.L.L.; CARGNELUTTI FILHO, A. \& PIRES, F.R. Ciclagem de nutrientes por plantas de cobertura na entressafra em um solo de cerrado. Pesq. Agropec. Bras., 42:1269-1276, 2007.

CALVO, C.L.; FOLONI, J.S. \& BRANCALIÃO, S.R. Produtividade de fitomassa e relação $\mathrm{C} / \mathrm{N}$ de monocultivos e consórcios de guandu-anão, milheto e sorgo em três épocas de corte. Bragantia, 69:77-86, 2010.

CARNEIRO, M.A.C.; CORDEIRO, M.A.S.; ASSIS, P.C.R.; MORAES, E.S.; PEREIRA, H.S.; PAULINO, H.B. \& SOUZA, E.D. Produção de fitomassa de diferentes espécies de cobertura e suas alterações na atividade microbiana de solo de cerrado. Bragantia, 67:455-462, 2008.

CARRÉ-MISSIO, V.; RODRIGUES, F.Á.; SCHURT, D.A.; REZENDE, D.C.; RIBEIRO, N.B. \& ZAMBOLIM, L. Aplicação foliar de silicato de potássio, acibenzolar-S-metil e fungicidas na redução da mancha de Pestalotia em morango. Trop. Plant Pathol., 35:182-185, 2010.

CARVALHO, W.P.; CARVALHO, G.J.; ABBADE NETO, D.O. \& TEIXEIRA, L.G.V. Desempenho agronômico de plantas de cobertura usadas na proteção do solo no período de pousio. Pesq. Agropec. Bras., 48:157-166, 2013.

CAZETTA, D.A.C.; FORNASIERI FILHO, D. \& GIROTTO, F. Composição, produção de matéria seca e cobertura do solo em cultivo exclusivo e consorciado de milheto e crotalária. Acta Sci. Agron., 27:575-580, 2005.

CHAGAS, R.C.S. Avaliação de fontes de silício para as culturas do arroz e milheto. Piracicaba, Centro de Energia Nuclear na Agricultura, Universidade de São Paulo, 2004. 80p. (Tese de Doutorado)

COSTA, C.H.M.; CRUSCIOL, C.A.C.; SORATTO, R.P. \& FERRARI NETO, J. Persistência e liberação de macronutrientes e silício da fitomassa de crotalária em função da fragmentação. Biosci. J., 28:384-394, 2012.

CRUSCIOL, C.A.C.; COTTICA, R.L.; LIMA, E.V.; ANDREOTTI, M.; MORO, E. \& MARCON, E. Persistência de palhada e liberação de nutrientes do nabo forrageiro no plantio direto. Pesq. Agropec. Bras., 40:161-168, 2005.

CRUSCIOL, C.A.C.; MORO, E.; LIMA, E.V. \& ANDREOTTI, M. Taxas de decomposição e de liberação de macronutrientes da palhada de aveia preta em plantio direto. Bragantia, 67:481-489, 2008.
CRUSCIOL, CA.C. \& SORATTO, R.P. Nitrogen supply for cover crops and effects on peanut grown in succession under a no-till system. Agron. J., 101:40-46, 2009.

CRUSCIOL, C.A.C. \& SORATTO, R.P. Nutrição e produtividade do amendoim em sucessão ao cultivo de plantas de cobertura no sistema plantio direto. Pesq. Agropec. Bras, 42:1553-1560, 2007.

FERRARI NETO, J.; CRUSCIOL, C.A.C.; SORATTO, R.P. \& COSTA, C.H.M. Consórcio de guandu-anão com milheto: Persistência e liberação de macronutrientes e silício da fitomassa. Bragantia, 71:264-272, 2012.

FERNANDEZ, F.A.; BULL, L.T.; CORRÊA, J.C. \& CRESPAM, D.R. Influência de silicato e calcário na decomposição de resíduos culturais e disponibilidade de nutrientes ao feijoeiro. R. Bras. Ci. Solo, 33:935-945, 2009.

GUNES, A.; INAL, A.; BAGCI, E.G. \& COBAN, S. Siliconmediated changes on some physiological and enzymatic parameters symptomatic of oxidative stress in barley grown in sodic-B toxic soil. J. Plant Physiol., 164:807-811, 2007.

KHATOUNIAN, C.A. O manejo da fertilidade em sistemas de produção. In: CASTRO FILHO, C. \& MUZILLI, O., coords. Uso e manejo dos solos de baixa aptidão agrícola. Londrina, IAPAR, 1999. p.179-221. (Circular, 108)

KLIEMANN, H.J.; BRAZ, A.J.P.B. \& SILVEIRA, P.M. Taxas de decomposição de resíduos de espécies de cobertura em Latossolo Vermelho distroférrico. Pesq. Agropec. Trop., 36:21-28, 2006.

KORNDÖRFER, G.H.; PEREIRA, H.S. \& CAMARGO, M.S. Silicatos de cálcio e magnésio na agricultura. Uberlândia, GPSi - ICIAG - UFU, 2002. 23p. (Boletim Técnico)

LANA, R.M.Q.; KORNDÖRFER, G.H.; ZANÃO JÚNIOR, L.A.; SILVA, A.F. \& LANA, A.M.Q. Efeito do silicato de cálcio sobre a produtividade e acumulação de silício no tomateiro. Biosci. J., 19:15-20, 2003.

LEITE, L.F.C.; FREITAS, R.C.A.; SAGRILO, E. \& GALVÃO, S.R.S. Decomposição e liberação de nutrientes de resíduos vegetais depositados sobre Latossolo Amarelo no Cerrado Maranhense. R. Ci. Agron, 41:29-35, 2010.

MALAVOLTA, E.; VITTI, G.C. \& OLIVEIRA, S.A. Avaliação do estado nutricional das plantas: Princípios e aplicações. Piracicaba, Potafós, 1997. 319p.

MARSCHNER, H. Mineral nutrition of higher plants. Amsterdam, Elsevier/Academic Press, 2012. 684p.

PAUL, E.A. \& CLARK, F.E. Soil microbiology and biochemistry. San Diego, Academic Press, 1989. 275p.

PERIN, A.; SANTOS, R.H.S.; URQUIAGA, S.; GUERRA, J.G.M. \& CECON, P.R. Produção de fitomassa, acúmulo de nutrientes e fixação biológica de nitrogênio por adubos verdes em cultivo isolado e consorciado. Pesq. Agropec. Bras, 39:35-40, 2004.

ROSOLEM, C.A.; CALONEGO, J.C. \& FOLONI, J.S.S. Lixiviação de potássio da palhada de espécies de cobertura de solo de acordo com a quantidade de chuva aplicada. R. Bras. Ci. Solo, 27:355-362, 2003. 
SALMI, G.P.; SALMI, A.P. \& ABBOUD, A.C.S. Dinâmica de decomposição e liberação de nutrientes de genótipos de guandu sob cultivo em aléias. Pesq. Agropec. Bras., 41:673678, 2006.

SILVA, A.G.; CRUSCIOL, C.A.C.; SORATTO, R.P.; COSTA, C.H.M. \& FERRARI NETO, J. Produção de fitomassa e acúmulo de nutrientes por plantas de cobertura e cultivo da mamona em sucessão no sistema plantio direto. Ci. Rural, 40:2092-2098, 2010.

SILVA, J.A.N.; SOUZA, C.M.A.; SILVA, C.J. \& BOTTEGA, S.P. Crescimento e produção de espécies forrageiras consorciadas com pinhão-manso. Pesq. Agropec. Bras, 47:769 775, 2012.

SORATTO, R.P.; CRUSCIOL, C.A.C.; COSTA, C.H.M.; FERRARI NETO, J. \& CASTRO, G.S.A. Produção, decomposição e ciclagem de nutrientes em resíduos de crotalária e milheto, cultivados solteiros e consorciados. Pesq. Agropec. Bras, 47:1462-1470, 2012.

SOUSA, J.V.; RODRIGUES, C.R.; LUZ, J.M.Q.; SOUSA, V.B.F.; CARVALHO, P.C.; RODRIGUES, T.M. \& BRITO, C.H. Silicato de potássio via foliar no milho: Fotossíntese, crescimento e produtividade. Biosci. J., 26:502-513, 2010.
TEDESCO, M.J.; GIANELLO, C.; BISSANI, C.A.; BOHNEN, H. \& VOLKWEISS, S.J. Análise de solo, plantas e outros materiais. Porto Alegre, Universidade Federal do Rio Grande do Solo, 1995. 174p. (Boletim Técnico, 5)

TEIXEIRA, C.M.; CARVALHO, G.J.; FURTINI NETO, A.E.; ANDRADE, M.J.B. \& MARQUES, E.L.S. Produção de biomassa e teor de macronutrientes do milheto, feijãode-porco e guandu-anão em cultivo solteiro e consorciado. Ci. Agrotec., 29:93-99, 2005.

TEIXEIRA, C.M.; CARVALHO, G.J.; ANDRADE, M.J.B.; SILVA, C.A. \& PEREIRA, J.M. Decomposição e liberação de nutrientes das palhadas de milheto e milheto + crotalária no plantio direto do feijoeiro. Acta Sci. Agron., 31:647 653, 2009.

THOMAS, R.J. \& ASAKAWA, N.M. Decomposition of leaf litter from tropical forage grasses and legumes. Soil Biol. Biochem., 25:1351-1361, 1993.

TORRES, J.L.R.; PEREIRA, M.G. \& FABIAN, A.J. Produção de fitomassa por plantas de cobertura e mineralização de seus resíduos em plantio direto. Pesq. Agropec. Bras, 43:421-428, 2008. 